\title{
BRAND CHARACTERISTICS' EFFECTS ON YEMENI COMPANIES' WILLINGNESS TO PAY (WTP) A PRICE PREMIUM FOR AUDIT SERVICES
}

\author{
Marwan Ghaleb ${ }^{1 *}$, Burçin Kaplan ${ }^{2}$ \\ ${ }^{1}$ Mr., Istanbul Aydin University, Turkey, marwan.m.ghaleb@gmail.com \\ ${ }^{2}$ Dr., Istanbul Aydin University, Turkey, burcinkaplan@aydin.edu.tr \\ ${ }^{*}$ Corresponding author
}

\begin{abstract}
Brand is considered as profitability enhancing factor and an element that will make consumers willing to pay a price premium. This research is working on studying the applicability of that for companies when consuming something and when they are operating in unstable country situation, by studying the effects of Brand Characteristics (including Brand Repetition, Brand Predictability, and Brand Competency) on consumer WTP a price premium mediated by Brand Credibility and Perceived Uniqueness for audit services comparing the companies' attitude toward branded (Big 4) and non-branded audit services in Yemen which as an example of unstable situation a country with an as per the world bank evaluation $2018-2019$. The data was collected from 200 company, that were audited in the last two years in Yemen, the structural equational modeling was used for analysis and results generating which revealed that: There are no direct effects of Brand characteristics (including Brand Repetition, Brand Predictability, and Brand Competency) to the consumer WTP a price premium for audit services in Yemen, the mediating role of Brand Credibility was only between Brand Predictability and consumer WTP a price premium and the mediating role of Perceived Uniqueness was only between Brand Competency and consumer WTP a price premium. This research is combining the Brand filed and the Audit filed by studying the effect of some brand variables on consumer behavior in a specialized service industry which is Auditing industry and concentrates on Brand effect from the consumer side, it contributes to the field of brand management, pricing strategy and, audit firms' management. It presents insight from a different point of view for audit firms' managerial practice in an unstable country situation.
\end{abstract}

Keywords: Brand Characteristics, Consumer (WTP) a price premium, Audit firms.

\section{INTRODUCTION}

Organizations and commercial projects have financial transactions, that translate the daily work into numbers language, these transactions must be recorded in an accounting system according to the company's accounting and documenting process in order to provide a financial information to its users such as management of the company, stockholders, creditors, financial analysts, and government agencies, this information helps them to make decisions related to the company and its overall business.

Financial transactions and related financial statements must be audited by an independent third party, to become more reliable and trustworthy. Auditing financial statements is "a systematic procedure that obtains and evaluates in an objective way the evidence related to assertions about financial actions and events to determine the degree of correspondence between those assertions and audit criteria established and 
planed, then communicates the results to the interested parties" (Soltani, 2007, p. 4). The main goal of auditing is giving an opinion that the financial statements are fairly stated and no sign of fraud and errs are there according to the sample selection of the accounting transactions of the company, related to the financial year under audit. (Ajao, et al., 2016, p. 033).

In order to give their financial statements, more credibility reliable and trustworthiness organizations preferred to be audited by a well-known, worldwide audit firm such as the big 4 . Getting audited by a wellknown audit firm will provide the organization more credibility and reliability, from marketing and branding point of view this can come under the Leveraging with a secondary brand which is: "Connecting the brand to some other entity in order to: establish a new set of associations from the entity to the brand which will affect the existing brand associations" (Keller, 2013, p. 261). Leveraging with a secondary brand main target is "to create a brand equity by connecting the brand to other information in the consumers memory that expresses a meaning to them" (Kotler \& Keller, 2016, p. 334), this will help to take advantage of the secondary brand associations that are already in the consumer mind and link them with the organization brand to find her a place in the consumer mind.

One way of connecting the brand or the organization with a third-party source is getting audited by a wellknown branded international audit firm, as a well-known name in the financial industry is always linked with credibility, accuracy, honesty, and trust, this what shapes the image of the audit firm and give an advantage to any organization that use an audit services presented by a well-known audit brand, as this will lead to share the credibility, accuracy, honesty values of the audit firm with the organization and give trust to its financial statements and numbers in front of the users of the financial statements and financial information. The stronger worldwide brand (name) of the audit firm, the better the leveraging effects, for example there are the big 4 audit firms: Deloitte, KPMG, PwC and EY, which are international strong brands in the audit industry, however as a result of such strong international brand name: the company have to pay a high amount of audit fees, the more the benefits from the brand the more fee will be paid, which may be less if the company get the audit service from a local or unknown audit firm.

Previous literature shows that there is a relation between the branded audit firm and the amount of audit fee it asks for, as the stronger and worldwide the brand name is the higher fee the audit firm will ask. For example, in Malaysia "Big 5 (branded Name) audit firms earn audit fee premiums of about 9.4 percent over the non-Big 5 ones" (Rahmat \& Iskandar, 2004, p. 20), this research also indicated that industry specialization firms do not generate audit fee premiums as same as branded industry specialization firms, another research done in Australia concluded that "that the audit fees of Big 8 (branded Name) auditors in Australasia includes a premium related to general brand name and industry specialization" (Craswell, et al., 1995 , p. 319). This will lead to concluding that any organization wants to be served by an international branded audit firm must pay more audit fee or price premium, but if most of the organizations want to have an international branded audit firm to audit their financial statements, are they willing to pay a high audit fee or a high price premium for taking the leveraging advantage of that international brand name? especially in a country like Yemen that is under an unstable situation according to world bank evaluation $2018-2019$.

Generally, "when, a high-quality products seller, can charge a higher price than the minimum average price of any similar high-quality product, the variance between such high price and a competitive price is called a price premium" (Dwivedi, et al., 2018, p. 101), this research discusses the consumer willing to pay (WTP) a price premium. WTP can be explained as the maximum amount that a consumer is willing to pay or spend to buy a product or service.

\section{LITERATURE REVIEW}

\subsection{Brand Characteristics as a Direct Effect}

The Brand Characteristics are "the essentials and fundamentals that present the true essence of the brand. They are a group of attributes that are identified as the physical, distinctive, and personality traits of the brand similar to that of an individual." (Bhasin, 2018), accumulating the characteristics of a product or a service perceived by a user will lead us to the main Brand Characteristics (Chaffey, 2015, p. 378). It creates a point of deference for the brand and gives it a competitive value in the market and give the consumers the ability to recognize the brand and be aware of it and connects with the targeted consumers emotionally and leads them to become loyal consumers to the brand as recalling it from the consumer mind will be much easier, which will lead to higher level of sales and increasing the organization profit on the long term (Lau \& Lee, 1999, p. 346). Such characteristics include many dimensions and take deferent formats according to each brand and each firm, this research adopted three dimensions of Brand Characteristics from (Lau \& Lee, 1999, p. 345) which are: Brand Reputation, Brand Predictability, and Brand Competence. 


\subsubsection{Brand Reputation}

How a brand is viewed by customers, stakeholders and the market in general, is a simple explanation of Brand Reputation, such view is a result of the ideas, feelings, and experience of the consumers when purchasing the brand or using it, a positive view will lead to a favourable Brand Reputation means that the customer gives his trust to the brand and feel proud of purchasing and using it and spread a positive word of mouth about it, successful organizations consider the Brand Reputation "as demand a source and permanent attractiveness, superior quality image and an added value that justifies a price premium" (Keller, 2013, p. 24).

Development of Brand Reputation can be done by advertisements and public relation so that a positive expectation about the brand can be developed, taking in consideration the influence of the product quality and performance so that it can achieve the consumer expectations, conforming this explanation (Lau \& Lee, 1999 , p. 346). Brand Reputation and other elements of the marketing mix are interacting together to make an influence such as the response of consumers to advertising" (Corkindale \& Belder, 2009, p. 249).

Deloitte one of the big 4 audit firms deal with Brand Reputation as a sensitive asset and "believes that they should never take the trust placed by their clients and the capital markets for granted, the integrity of Deloitte people and the quality of the services provided to the organizations and companies are the main part of their repetition foundation." (Deloitte, 2016, pp. 8, 11).

\subsubsection{Brand Predictability}

Brand Predictability is "the level of accuracy that a consumer can anticipate a consistent degree of product quality or service" (Kim \& Jones, 2009, p. 283). A brand is predictable, "when the user is able to anticipate, with reasonable confidence, the brand future performance at each usage instance" (Lau \& Lee, 1999, p. 346), it comes from a repeated interaction with the brand, it also enhances customer confidence of the brand as he knows that no unexpected things will happen while using it, which will lead to a positive expectation about the brand.

Audit firms work on maintain and increasing positive expectations from their clients, as from a consumer of audit services point of view some expectations are developed and predicted to be found in a Branded audit firm, so audit firms stress on some points that their clients are predicting from them, as "Sharing and distributing information about different elements of the brand will decrease the asymmetry and uncertainty of information, and increases Brand Predictability (Mosavi \& Kenarehfard, 2013, p. 75). KPMG one of the big 4 audit firms insists on "delivering quality service to their clients in line with qualifications, professional commitments, and engagement terms, maintaining independence and objectivity, and avoiding conflicts of interest or undue influence and preserves client and business confidentiality and privacy, in order to meet their clients' expectations and predictions." (KPMG, 2005, p. 5).

\subsubsection{Brand Competence}

"A competent brand is the brand that is able to solve consumers' problems and meet their requests and needs. Consumers may found about such competencies through direct usage or word of mouth communication, once they found about the brand-ability of solving their problems they may be willing to rely on that brand" (Lau \& Lee, 1999, pp. 346-347), "Brand Competence is important for creating, developing and protecting brands that have its own identity" (Urde, 1999, p. 117), In addition to that "Previous experience of brand usage with positive perception could strengthen brand competence" (Setyawan, et al., 2015, p. 44).

Brand Competency is an important branding element of an audit firm brand, PwC one of the big 4 audit firms considers their professional competence and integrity as sours of the client's trust and quality that underpin their reputation. (PwC, 2011, p. 6). It is an accumulated process as per EY one of the big 4 they support their employees' professional development, recognize individuals' achievements, and take care of continuous learning as a leveraging source of their employees' competencies which will affect the overall firm competence positively (EY, 2017, p. 6).

From the previous dissection, it is concluded that Brand Characteristics are an important factor for each organization and leads to several branding factors, in this research, their relation will be examined with the WTP a price premium for auditing services.

H1. Brand Characteristics (which includes a. Brand Repetition, b. Brand Predictability, and c. Brand Competency) have a significant impact on Consumers' WTP a Price Premium. 


\subsection{Brand Credibility and Perceived Uniqueness Mediating Role}

\subsubsection{Brand Credibility}

A credible brand "is able (expertise) and willing (trustworthiness) to stay true and is committed to performance-enhancing" (Dwivedi, et al., 2018, p. 101), Credibility can be gain by repeated satisfying interaction with the brand by the consumer, as a predictable and a reliable performance form the brand over time "it significantly support and effects on other brand functions, such as information efficiency and risk reduction, and lead to customers repurchase intentions" (Leischnig, et al., 2012, p. 44), "Brand Credibility has a strong effect on purchase intention as it increases the perceived quality and the perceived value for money and information costs saved, it also decreases the perceived risk across multiple service categories" (Baek \& King, 2011, p. 260), "it plays a role in consumers' price perception, as it can decrease their price sensitivity, increase acceptance of price changing and enhance consumers' WTP a higher price" (Erdem, et al., 2002, p. 1), as it "effects brand image and purchase intention positively" (Martín-Consuegra, et al., 2018, p. 237) and (Xuehua \& Yang, 2010, p. 177).

From a leveraging point of view an organization can increase its credibility by linking itself with one that is already considered credible in the market, one way of doing that is getting audited by a well-known branded audit firm, it is important for an audit firm to show credibility in its operation and behavior with its clients to maintain a good repetition and gain trust as those are the main components of the intangible capital of an audit firm (Keller, 2013, p. 261).

H2. Brand Credibility significantly mediates the relationship between Brand Characteristics (which includes a. Brand Repetition, b. Brand Predictability, and c. Brand Competency) and Consumers' WTP a Price Premium such that:

1. Brand Characteristics (which includes a. Brand Repetition, b. Brand Predictability, and c. Brand Competency) significantly influences Brand Credibility, and

2. Brand Credibility significantly influences Consumers' WTP a Price Premium.

\subsubsection{Perceived Uniqueness}

Perceived Uniqueness: "The special element of a brand which makes it different from other brands" (Dwivedi, et al., 2018, p. 102). This means that the brand must have a strong point of deference that shows how much the brand is noticed, recognized and recalled comparing to other brands, this can be achieved by creating and sustaining unique associations with the consumers, this will separate the brand from competition by providing an added value to the consumer which will lead to affect their WTP a price premium positively as Perceived Uniqueness is a key reason for which consumers may pay the price premiums (Dwivedi, et al., 2018, p. 102), also, "by creating uniqueness, brands have the chance to create an emotional connection, and make a difference" (Kotler \& Pfoertsch, 2006, p. 319), as "the actual brand choices made by consumers usually made according to the perceived uniqueness of such brand associations" (Keller, 2013, p. 83).

Providing an audit or a financial service may be the same to consumers as it depends on the standard audit procedures and standard financial processes so each audit firm is working on having its own unique identity in the audit firm attitude with their clients, the professionalism of their employees and the professional certifications that they have, and overall the high quality of the services they provide, audit firms work on developing a culture of appropriate professional scepticism and personal accountability which supports clients and drives quality in the services they provide which lead to be unique" (Deloitte, 2016, p. 3).

H3. Perceived Uniqueness significantly mediates the relationship between Brand Characteristics (which includes a. Brand Repetition, b. Brand Predictability, and c. Brand Competency) and Consumers' WTP a Price Premium such that:

1. Brand Characteristics (which includes a. Brand Repetition, b. Brand Predictability, and c. Brand Competency) significantly influences Perceived Uniqueness, and

2. Perceived Uniqueness significantly influences Consumers' WTP a Price Premium 


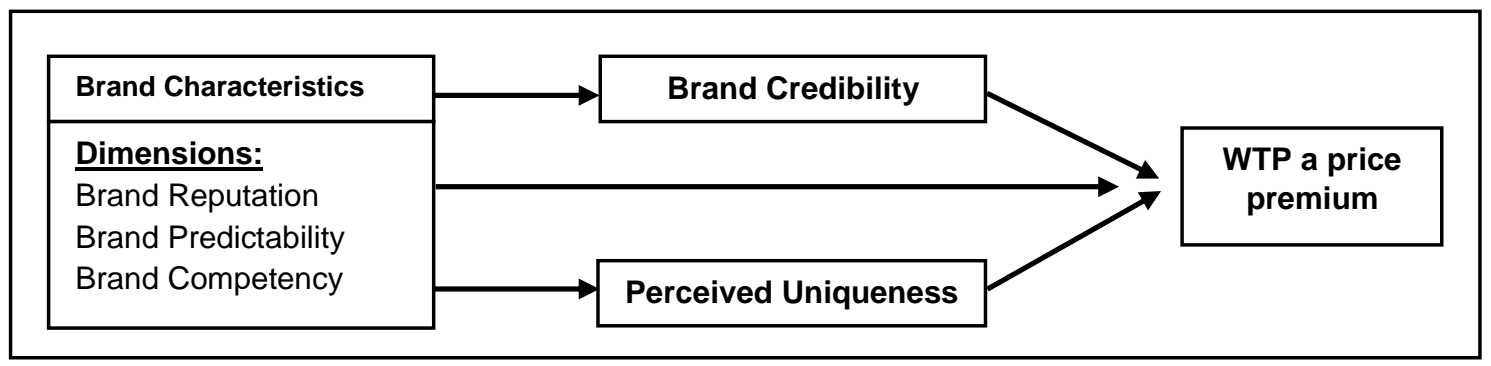

Figure 1. Conceptual frame work

\section{METHODOLOGY}

\subsection{Research Design, Population and Sampling Method}

A quantitative research approach has been designed and implemented, as this research is formed "according to the meanings taken from numbers, results collected in a numerical standardized form and analysis directed by diagrams and statistics" (Saunders, et al., 2009, p. 482), such numerical data was collected from a specific sample that represent the whole population in Yemen.

An online self-administered survey was used to collect part of the primary data, as surveys help to collect data from a large sample of individuals who are questioned about their opinions and views, online survey was used as it saves time and cost of collecting the needed data and helps to reach a wide audience wherever their geographical location is (Ilieva, et al., 2002, p. 363), the survey participants were requested to respond to the two main parts of the survey, the first part was the demographics data part, which helps to understand more about the respondent and his/her relation with the survey topic. The second part was about the variables related questions that will help to test the research hypotheses, an explanation about the research topic, goals and research population and targeted sample with some guidelines was provided prior to the survey questions.

As this research is implemented in audit industry the target was any company that has been audited by any audit firm, in each company the final decision of selecting the external auditor is taken by the board of directors, taking in consideration the opinion of the general management and finance department. Financial departments represented by accountants of each organization are responsible for dealing with the auditors while auditing is done and they are representing the organization top management views and decision in front of the audit team. According to that, the targeted population is top management, financial management, and accountants in organizations that get external audit services in Yemen.

a convenience sampling method which is one of the non-probability sampling methods was used to select the target respondents, it "targets respondents that meet certain practical criteria and considered as a convenient source of data for the research" (Etikan, et al., 2016, p. 2). a target of 200 samples was determined as "200 observations will lead to 7\% errors in prediction accuracy" (Varoquaux, 2018, p. 72), only one response was obtained from each organization in order to cover deferent companies' opinions and experiences, responses represent 84 company that has been audited by a branded audit firm and 116 by non-branded audit firm.

Demographic question was used to determine if the respondents are applicable to participate in this study, first part of the demographic questions included two questions related to the position of the respondent and his/her years of experience, such questions will help to have an idea about how much the respondent is involved in the external auditor selecting decision and how much experience he/she has in the financial work, while the second part included two questions related to the frequency of the external auditing process in the organization is it yearly, every 6 months or quarterly and when the last time the organization had its financial statements audited, this will help to get more idea about how regular the organization deals with the audit firms and how the relative information is fresh in the respondents' memory.

The results of the demographic data shown in table. 1 lead to conclude that the targeted respondents of this research have appropriate criteria and characteristics that made them appropriate to participate in this research. 
Table 1. Respondents' portfolio of this study

\begin{tabular}{|l|l|c|c|}
\hline Descriptors & Sub-descriptors & Frequency $(\mathrm{n}=200)$ & Percentage \\
\hline \multirow{4}{*}{ Position } & Staff level. & 30 & $15 \%$ \\
\cline { 2 - 4 } & Supervising level. & 86 & $43 \%$ \\
\cline { 2 - 4 } & Managerial level or above. & 84 & $42 \%$ \\
\hline \multirow{3}{*}{$\begin{array}{l}\text { Years of } \\
\text { experience }\end{array}$} & Total & 200 & $100 \%$ \\
\hline \multirow{3}{*}{$\begin{array}{l}\text { Frequency of } \\
\text { auditing process }\end{array}$} & S years or less & 31 & $15.5 \%$ \\
\cline { 2 - 4 } & More than 5 years, to 10 years. & 75 & $37.5 \%$ \\
\cline { 2 - 4 } & More than 10 years. & 94 & $47 \%$ \\
\cline { 2 - 4 } & Total & 200 & $100 \%$ \\
\cline { 2 - 4 } & Query 6 months. & 174 & $87 \%$ \\
\hline \multirow{3}{*}{ Last time audited } & Total & 13 & $6.5 \%$ \\
\cline { 2 - 4 } & Before 2 years. & 200 & $100 \%$ \\
\cline { 2 - 4 } & Last Year. & 24 & $12 \%$ \\
\cline { 2 - 4 } & This year. & 124 & $62 \%$ \\
\hline & Total & 200 & $100 \%$ \\
\hline
\end{tabular}

\subsection{Data Collecting Instrument}

The collection of the data was done by a survey which was adapted from two articles, the independent variables questions (Brand Characteristics) was adopted from (Lau \& Lee, 1999, p. 364) while the mediators (Brand Credibility and Perceived Uniqueness) and dependent variable (WTP a Price Premium) questions was adopted from (Dwivedi, et al., 2018, p. 103), using a 5 point Likert scale $(1=$ Strongly disagree, $2=$ Disagree, 3 = Neutral, $4=$ Agree, $5=$ Strongly agree) such close-ended questions type was selected as it needs the minimum writing activity which makes it easy and less time consuming for the respondent.

\subsection{Statistical Techniques:}

The statistical techniques used are Confirmatory Factor Analysis (CFA) and Structural Equational Modelling (SEM). Confirmatory Factor Analysis (CFA) is considered as the first step of the SEM analysis as it confirms the reliability of the data collected and the validity of the measures, it confirms "to what extent, observed variables are linked to their underlying factors" (Byrne, 2012, p. 6). CFA analysis measures the relationship between the observed variables themselves (reliability) and their relation with their observed variable (validity), on the other hand Structural Equational Modelling (SEM) helps to test "various theoretical models, that hypothesize how sets of variables define constructs and how these constructs are related to each other in a quantitative manner" (Schumacker \& Lomax, 2010, p. 2), it tests the structural path between variables but CFA confirm the relation between latent and observed variables.

Analysis software used for this research is IBM SPSS version 23 and IBM SPSS AMOS version 22.

\section{ANALYSIS AND FINDINGS}

\subsection{Confirmatory Factor Analysis (CFA), reliability and validity assessment}

CFA analysis help to identify the reliability and validity of the data collected: Reliability "is the level that the test scores are free from measurement error or the elements of errors that occur when testing something. Having an unreliable measurement will lead to insignificant relationship between variables and inaccurate results" (Muijs, 2004, p. 71), if the reliability test results (Composite Reliability) were above 0.70 then the measurement is reliable to be used ( $C R \geq 0.70$ ) (Muijs, 2004, p. 73), on the other hand Validity: "lead to 
answer the question, are we measuring what we are willing to measure? So, it works on confirming if the variables are being measured accurately or not, especially the variables that can't be measured directly (latent variables)" (Muijs, 2004, p. 71). Validity can be divided into Convergent Validity which indicates "to what level two measures of the same variable are correlated", and Discriminant Validity which indicates "to what level two conceptually similar concepts are separated" (Hair Jr, et al., 2014, p. 124), to get an accepted validity you have to get an Average Variance Extracted higher than or equal to 0.5 (AVE $\geq 0.5$ ) and a Maximum Shared Variance that is less than the Average Variance Extracted (MSV > AVE) (Gefen \& Straub, 2005, pp. 93-94).

The results of Reliability and Validity Assessment for all variables in table shows that: Reliability is greater than 0.70 (CR $\geq 0.70$ ), Convergent Validity is more than 0.50 (AVE $\geq 0.50$ ) and MSV is less than AVE for Discriminant Validity (MSV < AVE), lead to conclude that the responses got from respondents are reliable and valid.

Table 2. Reliability and validity

\begin{tabular}{|c|c|c|c|c|c|c|c|c|c|c|}
\hline & CR & AVE & MSV & $\operatorname{MaxR}(\mathrm{H})$ & PU & BR & BP & BC & BCr & WTP \\
\hline PU & 0.825 & 0.543 & 0.491 & 0.836 & 0.737 & & & & & \\
\hline BR & 0.700 & 0.500 & 0.216 & 0.765 & 0.408 & 0.661 & & & & \\
\hline BP & 0.733 & 0.501 & 0.227 & 0.868 & 0.260 & 0.192 & 0.708 & & & \\
\hline BC & 0.773 & 0.541 & 0.491 & 0.858 & 0.701 & 0.465 & 0.376 & 0.735 & & \\
\hline BCr & 0.773 & 0.510 & 0.257 & 0.807 & 0.507 & 0.357 & 0.476 & 0.490 & 0.684 & \\
\hline WTP & 0.803 & 0.581 & 0.220 & 0.839 & 0.469 & 0.138 & 0.145 & 0.358 & 0.359 & 0.762 \\
\hline
\end{tabular}

While: BR is Brand repetition, BP is Brand predictability, BC is Brand competency, BCr is Brand credibility, PU is Perceived uniqueness and WTP is willing to pay a price premium.

\subsection{SEM Hypotheses Testing}

Using SPSS AMOS, the hypothesis structural model was created, this model shows the relation between the research latent variables where several regression equations take place. The model shows the direct effect between independent and dependent variables and indirect relationship between independent and dependent variables.

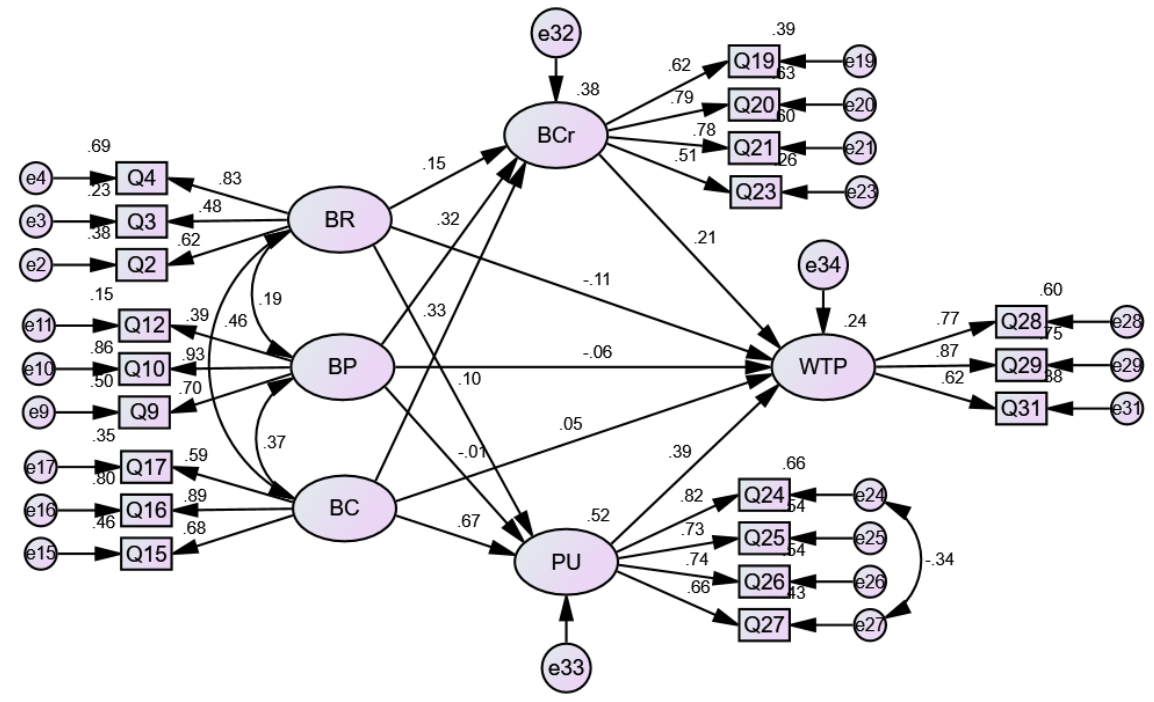

Figure 2 Hypothesis structural model - Yemen

According to the P-value results shown in table 3 , it is concluded that there is no relationship between Brand Repetition and Consumers' WTP a Price Premium, Brand Predictability and Consumers' WTP a Price Premium or Brand Competency and Consumers' WTP a Price Premium in Yemen and this will lead to rejecting the first hypothesis.

The P-value relates to the second hypothesis shown in table 3 , lead to conclude that there is no effect of 
Brand Credibility as a mediator between Brand Repetition and Consumer WTP a Price premium but this effect is strong between Brand Predictability and Consumer WTP a Price premium and moderate between Brand Competency and Consumer WTP a Price premium only in Yemen, however, this is not enough to conclude that it has a significant or strong effect.

The P-value related to the third hypothesis shown in table 3 lead to conclude that Perceived Uniqueness does not mediate the relation between Brand Repetition and Consumers' WTP a Price Premium and between Brand Predictability and Consumers' WTP a Price Premium but there is a very strong mediating effect between Brand Competency and Consumers' WTP a Price Premium in Yemen.

Table 3. Hypothesis testing results

\begin{tabular}{|c|c|c|c|}
\hline & Relationships & P-value & Interpretation \\
\hline H1a & Brand Repetition $\rightarrow$ WTP & 0.256 & Not Supported \\
\hline H1b & Brand Predictability $\rightarrow$ WTP & 0.542 & Not Supported \\
\hline H1c & Brand Competency $\rightarrow$ WTP & 0.707 & Not Supported \\
\hline H2a & Brand Repetition $\rightarrow$ Brand Credibility $\rightarrow$ WTP & 0.102 & Not Supported \\
\hline H2b & Brand Predictability $\rightarrow$ Brand Credibility $\rightarrow$ WTP & 0.028 & Supported \\
\hline H2c & Brand Competency $\rightarrow$ Brand Credibility $\rightarrow$ WTP & 0.061 & Not Supported \\
\hline H3a & Brand Repetition $\rightarrow$ Perceived Uniqueness $\rightarrow$ WTP & 0.202 & Not Supported \\
\hline H3b & Brand Predictability $\rightarrow$ Perceived Uniqueness $\rightarrow$ WTP & 0.904 & Not Supported \\
\hline H3c & Brand Competency $\rightarrow$ Perceived Uniqueness $\rightarrow$ WTP & 0.005 & Supported \\
\hline
\end{tabular}

\section{ANALYSIS AND FINDINGS}

Brand Characteristics (including Brand Repetition, Brand Predictability, and Brand Competency) do not affect Consumer Willingness to Pay a Price Premium in Audit Industry in Yemen part of this finding is confirmed by (Ward, et al., 1994, p. 399) as they found that "research has not documented reputation effects for audit fee for non-Big 6 firms" as the effect of reputation is the same whether the audit firm is branded or not.

This will lead to conclude that: What is applicable in other industries is not applicable for audit services industry, as according to (Dwivedi, et al., 2018, p. 105) brand has an effect on consumer willingness to pay a price premium in automobile industry, and according to (Anselmsson, et al., 2014, p. 90) brand has an effect on consumer willingness to pay a price premium in restaurants and food industries, this is also applicable in the airlines industry according to (Garrow, et al., 2007, p. 271) and (Kuo \& Jou, 2017, p. 134), also the consumer behaver toward the brand for individuals is different than the organizations as they are restricted to the target of decreasing costs and increasing profits.

In addition to that according to (Firer \& Swartz, 2006, p. 1) and (Naser \& Nuseibeh, 2008, p. 239) find out that the mine factors affecting the audit fee are the client size, risk and the complexity of his business, such results are confirming the finding of (Cullinan, 1997, p. 91) which is: "client characteristics, including client size and risk, are the main factors of determining audit fees and no difference between big six audit firms and non-big six audit firms in this fee structure".

Brand Credibility does not play a mediating role between Brand Characteristics (including Brand Repetition, and Brand Competency) and Consumer Willingness to Pay a Price Premium in Audit Industry, but it has a mediating role between Brand Predictability and Consumer Willingness to Pay a Price Premium in Audit Industry, as the more the brand is credible and honest the more the client will be able to predict its performance.

This will lead to conclude that: Although Credibility is essential for any brand, it has no significant effect in Audit industry even though it affects some variables, because credibility for audit firms is essential and monitored by law and there are negative consequences if any audit firm brakes the credibility law, so the audit clients take credibility for granted and audit firms cannot debate for increasing their fees based on their credibility, the main example supporting this conclusion is what happened to Arthur Andersen one audit firm that used to be one of the Big Five audit firms and one of the worldwide multi-national audit firms but in 2001 
"the US government represented by the US Department of Justice decided to prosecute Andersen as a firm" (Asthana, et al., 2009, p. 4) due to the scandal of Enron Energy Corporation as it reported that their financial condition is sustained but after their bankruptcy the investigations reviled that it was reported by a creatively planned accounting fraud, and this fact was ignored by Arthur Andersen the audit firm while auditing as they didn't modify their reports after finding some external events evidence and going concern issue (Nogler, 2007, p. 51), and that caused them to surrendered their licenses to practice as an audit firm. So credibility is a main issue for an audit firm which will lead to legal consequences if ignored by the audit firm and such value does not have a great power when negotiating for audit fee, but according to what happened to Arthur Andersen audit firms debate that the risk they are facing and their responsibility was increased so accordingly they have to increase their fees (Asthana, et al., 2009, p. 4).

Perceived Uniqueness does not play a mediating role between Brand Characteristics (including Brand Repetition and Brand Predictability) and Consumer Willingness to Pay a Price Premium in Audit Industry in Yemen but it has a mediating role between Brand Competency and Consumer Willingness to Pay a Price Premium in Audit Industry. This research was done in 2018-2019 while Yemen as a country has economic crises and unstable situation, organizations are not considering the uniqueness of audit firms a value and it is difficult for them to be willing to pay a price premium for a branded audit services, even for a well-known name that has a unique industry specialization value, such finding was confirmed by the finding of (Sonu, et al., 2017, p. 127) as they found out that "audit fees are significantly decreased during financial crises as the clients are under high pressure of reducing expenses" also (Groff, et al., 2017, p. 922) found out that "financial crisis negatively affected audit fees in Slovenia and the ability of clients to pay a price premium". This will lead us to see the difference between consumer behavior in stable and unstable country situation.

\subsection{Implications and recommendations}

- As recommended by (Siddiqui, et al., 2013, p. 332) it is recommended that audit firms review their audit fees scale to be more competitive especially when they are operating in an unstable economic situation or an emerging market.

- To target medium and small companies more and more with an appropriate audit fee scale, as these companies need the leveraging value more especially in an unstable economical station as they are trying to get loans and grants to survive and getting audited by an international branded audit will give them more value inform of the granter or the donor.

- To be updated with the accounting and auditing standards, local laws and regulations, and present valuable observations and recommendations and work on proving their uniqueness during their filed work auditing process.

- To put a target to be an industry specialist audit firm in more than one industry to get more competitive value in the market and work on growing their other services beside audit such as consulting, tax declaration review and other accounting services.

\subsection{Limitations and Suggestions for further researches}

- This research discussed only three dimensions of the Brand Characteristics Brand Repetition, Brand Predictability and Brand competency, two brand variables as mediators Brand Credibility and Perceived Uniqueness, three Variables as moderators Brand Familiarity, Product Category Involvement and Consistency of Brand Image.

- Limitation in getting cooperation from some targeted companies.

- Limitation in the time period and related conditions in 2018-2019 in Yemen.

For further researches in the same filed and in order to add more value to such filed, it is suggested that:

- Implement the same idea in other countries worldwide to compare the organization behavior toward the branded audit firms' fees.

- Implement the same idea of the effects of brand characteristics on the prices in deferent industries to be able to compare the results between more industries.

- Study other characteristics of the brand and other variables of the brands on the WTP a price premium and their direct, mediating and moderating effects such as Brand Trust, Brand experience, Brand Loyalty and others.

- As same as (Lau \& Lee, 1999, p. 345) they studied in addition to the Brand characteristics, the Company Characteristics and Consumer- Brand Characteristics on the Brand Loyalty, so it is suggested to adopt the other two Characteristics they used as in independent variables (Company Characteristics and Consumer- Brand Characteristics) and study their effects on the Consumer WTP a Price Premium. 


\section{REFERENCE LIST}

Ajao, O. S., Olamide, J. O., \& Temitope, A. A. (2016). Evolution and development of auditing. Unique Journal of Business Management Research, 3(1), 032-040.

Ansary, A., \& Hashim, N. M. (2018). Brand image and equity: the mediating role of brand equity drivers and moderating effects of product type and word of mouth. Review of Managerial Science, 12, 9691002.

Baker, W., Hutchinson, J. W., Moore, D., \& Nedungadi, P. (1986). Brand Familiarity and Advertising: Effects on the Evoked Set and Brand Preference. Advances in Consumer Research, 13, 637-642.

Belanche, D., Flavián, C., \& Pérez-Rueda, A. (2017). Understanding Interactive Online Advertising: Congruence and Product Involvement in Highly and Lowly Arousing, Skippable Video Ads. Journal of Interactive Marketing, 37, 75-88.

Bengtsson, A., Bardhi, F., \& Venkatraman, M. (2010). International Marketing Review. How global brands travel with consumers: An examination of the relationship between brand consistency and meaning across national boundaries, 27(5), 519-540.

Bhasin, H. (2018). What are Brand Characteristics? Retrieved November 27, 2018, from https://www.marketing91.com/what-are-brand-characteristics/

Byrne, B. M. (2010). Structural Equation Modeling with AMOS Basic Concepts, Applications, and Programming (2nd ed.). New York: Taylor and Francis Group, LLC.

Byrne, B. M. (2012). Structural Equation Modeling with Mplus Basic Concepts, Applications, and Programming (2nd ed.). New York: Taylor \& Francis Group, LLC.

Byrne, B. M. (2016). Structural Equation Modeling with Amos: Basic Concepts, Applications, and Programming (3ed ed.). New York: Routledge.

Campbell, J., DiPietro, R. B., \& Remar, D. (2014). Local foods in a university setting: Price consciousness, product involvement, involvement, price/quality inference and consumer's willingness-to-pay. International Journal of Hospitality Management, 42, 39-49.

Carvalho, J., \& Chima, F. O. (2014). Applications of Structural Equation Modeling in Social Sciences Research. American International Journal of Contemporary Research, 4(1), 6-11.

Chaffey, D. (2015). Digital Business and E-Commerce Management (6th ed.). United Kingdom: Pearson Education Limited.

Craswell, A. T., Francis, J. R., \& Taylor, S. L. (1995). Auditor brand name reputations and industry Specializations. Journal of Accounting and Economics, 20, 297-322.

Deloitte. (2016). Code of Ethics and Professional Conduct The power of shared values. UK: Deloitte Development LLC.

Dharmesti, M. D., \& Nugroho, S. S. (2012). The Antecedents of Online Customer Satisfaction and Customer Loyalty. The Business \& Management Review, 3(1), 37-42.

Drossos, D. A., Kokkinaki, F., Giaglis, G. M., \& Fouskas, K. G. (2014). The effects of product involvement and impulse buying on purchase intentions in mobile text advertising. Electronic Commerce Research and Applications, 13, 423-430.

Dwivedi, A., Nayeem, T., \& Murshed, F. (2018). Brand experience and consumers' willingness-to-pay (WTP) a price premium: Mediating role of brand credibility and perceived uniqueness. Journal of Retailing and Consumer Services, 44, 100-107.

Etikan, I., Musa, S. A., \& Alkassim, R. S. (2016). Comparison of Convenience Sampling and Purposive Sampling. American Journal of Theoretical and Applied Statistics, 5(1), 1-4.

EY. (2013). Building a better working world. International: EYGM Limited.

Gaskin, J. (2017, July 11). Data screening. Retrieved February 21, 2019, from http://statwiki.kolobkreations.com/index.php?title=Data_screening\#Linearity

Gaskin, J. (2018). Structural Equation Modeling. Retrieved February 26, 2019, from http://statwiki.kolobkreations.com/index.php?title=Structural_Equation_Modeling 
Gefen, D., \& Straub, D. (2005). A Practical Guide to Factorial Validity Using PLS Graph: Tutorial and Annotated Example. Communications of the Association for Information Systems, 16(5), 91-109.

Hair Jr, J. F., Black, W. C., Babin, B. J., \& Anderson, R. E. (2014). Multivariate Data Analysis (7th ed.). England: Pearson Education Limited.

Hooper, D., Coughlan, J., \& Mullen, M. R. (2008). Structural Equation Modelling: Guidelines for Determining Model Fit. Electronic Journal of Business Research Methods, 6(1), 53-60.

Hox, J. J., \& Bechger, T. M. (1999). An Introduction to Structural Equation Modeling. Family Science Review, 11, 354-373.

Hu, L.-t., \& Bentler, P. M. (1999). Cutoff Criteria for Fit Indexes in Covariance Structure Analysis: Conventional Criteria Versus New Alternatives. Structural Equation Modeling: A Multidisciplinary Journal, 5(1), 1-55.

Hung, H. J., O'Neill, R. T., Bauer, P., \& Kohne, K. (1997). The Behavior of the P-Value When the Alternative Hypothesis is True. Biometrics, 53(1), 11-22.

Ilieva, J., Baron, S., \& Healey, N. M. (2002). Online surveys in marketing research: pros and cons. International Journal of Market Research, 44(3), 361-376.

Kapferer, J.-N. (2008). The New Strategic Brand Management (4th ed.). London and Philadelphia: Kogan Page Limited.

Keller, K. L. (1993). Conceptualizing, Measuring, and Managing Customer-Based Brand Equity. Journal of Marketing, 57(1), 1-22.

Keller, K. L. (2013). Strategic Brand Management (4th Global ed.). London: Pearson Education Limited.

Kim, S., \& Chung, H. (2012). The impacts of perceived fit, brand familiarity, and status consciousness on fashion brand extension evaluation. International Journal of Fashion Design, 5(3), 203-211.

Kline, R. B. (2011). Principles and Practice of Structural Equation Modeling (3ed ed.). New York: THE GUILFORD PRESS.

Kotler, P., \& Keller, K. L. (2016). Marketing Management (15th Global ed.). London: Pearson Education Limited.

Kotler, P., \& Pfoertsch, W. (2006). B2B Brand Management (1st ed.). Heidelberg: Springer Berlin.

Landau, S., \& Everitt, B. S. (2004). A Handbook of Statistical Analyses using SPSS (1st ed.). London: Chapman \& Hall/CRC Press LLC.

Lanseng, E. J., \& Olsen, L. E. (2012). Brand alliances: the role of brand concept consistency. European Journal of Marketing, 46(9), 1108-1126.

Lau, G. T., \& Lee, S. H. (1999). Consumers' Trust in a Brand and the Link to Brand Loyalty. Journal of Market-Focused Managment, 4, 341-370.

Liang a, Y.-P. (2012). The Relationship between Consumer Product Involvement, Product Knowledge and Impulsive Buying Behavior. Procedia - Social and Behavioral Sciences, 57, 325 - 330.

Muijs, D. (2004). Doing Quantitative Research in Education with SPSS (1st ed.). London: Sage Publications.

Ogba, I.-E., \& Tan, Z. (2009). Exploring the impact of brand image on customer loyalty and commitment in China. Journal of Technology Management in China, 4(2), 132-144.

Park, S. C., \& Keil, M. (2017). The Moderating Effects of Product Involvement on Escalation Behavior. Journal of Computer Information Systems, 57, 1-15.

Rahmat, M. M., \& Iskandar, T. M. (2004). Audit fee premiums from brand name, industry specialization and industry leadership: A study of the post Big 6 merger in Malaysia". Asian Review of Accounting, 12(2), 1-24.

Roy, D., \& Banerjee, S. (2014). Identification and measurement of brand identity and image gap: a quantitative approach. Journal of Product \& Brand Management, 23(3), 207-219.

Saunders, M., Lewis, P., \& Thornhill, A. (2009). Research methods for business students (5th ed.). Harlow: Pearson Education Limited. 
Schumacker, R. E., \& Lomax, R. G. (2010). A Beginner's Guide to Structural Equation Modeling (3rd ed.). New York: Taylor and Francis Group, LLC.

Sheau-Fen, Y., Sun-May, L., \& Yu-Ghee, W. (2012). Store brand proneness: Effects of perceived risks, quality and familiarity. Australasian Marketing Journal, 20, 48-58.

Soltani, B. (2007). AUDITING: An International Approach (1st ed.). England: Pearson Education Limited.

Till, B. D., Baack, D., \& Waterman, B. (2011). Strategic brand association maps: developing brand insight. Journal of Product \& Brand Management, 20(2), 92-100.

Vaidyanathan, R. (2000). The Role of Brand Familiarity in Internal Reference Price Formation: An Accessibility-Diagnosticity Perspective. Journal of Business and Psychology, 14(4), 605-624.

Varoquaux, G. (2018). Cross-validation failure: Small sample sizes lead to large error bars. Neurolmage, 180, 68-77. 